\title{
PENGARUH PENGGUNAAN TEPUNG LABU KUNING (Cucurbita Moschata Durch) TERHADAP KARAKTERISTIK CHIFFON CAKE BERBAHAN DASAR MODIFIED CASSAVA FLOUR (MOCAF)
}

\author{
Komang Biandari Devi Permatasari ${ }^{1}$, Putu Timur Ina ${ }^{2}$, Ni Made Yusa ${ }^{2}$ \\ ${ }^{1}$ Mahasiswa Program Studi Imu dan Teknologi Pangan, Fakultas Teknologi Pertanian, Unud \\ ${ }^{2}$ Dosen Program Studi Imu dan Teknologi Pangan, Fakultas Teknologi Pertanian, Unud \\ E-mail: biandari.devi@gmail.com ${ }^{1}$
}

\begin{abstract}
The purpose of this research is to know the effect of pumpkin flour and ratio mocaf on the characteristics of chiffon cake and to know the right ratio for pumpkin flour and mocaf to produce chiffon cake with the best characteristics. The experimental design used is randomized block design with the treatment ratio of pumpkin flour with mocaf $10 \%: 90 \% ; 20 \%: 80 \% ; 30 \%$ : 70\%; 40\%:60\%; 50\%: 50\%; and 60\%: 40\%. The treatment was repeated 3 times to get 18 units of the experiment. The data obtained from the result research were analyzed by variance and if the treatment had an effect on the variable then continued with Duncan test. The results showed that the ratio of pumpkin flour and mocaf had significant effect on water and ash content, total carotenoid, unfolding factor, hedonic test (colour, aroma, texture, taste, pores uniformity and overall acceptance), and scoring test (colour, aroma, taste, pores uniformity) of chiffon cake. Ratio of 30\% pumpkin flour : 70\% mocaf has the best characteristic with $36.65 \%$ water content, $1.38 \%$ ash content, $511.65 \%$ unfolding factor, $27.39 \mu \mathrm{g} / \mathrm{g}$ total carotenoid, pores uniformity is uniform and liked, color yellow and liked, flavor pumpkin medium and rather liked, texture soft and liked, taste rather typical pumpkin and liked and overall acceptance liked.
\end{abstract}

Keywords : pumpkin flour, mocaf, chiffon cake

\section{PENDAHULUAN}

$$
\text { Cake merupakan salah satu }
$$

makanan yang digemari masyarakat Indonesia dari anak-anak sampai lanjut usia. Chiffon cake merupakan salah satu jenis cake yang memiliki tekstur ringan, lembut disertai pori-pori yang relatif lebih besar dibanding cake lainnya, serta dibuat dari terigu, kuning telur, putih telur, baking powder, gula dan minyak (McWilliams, 1997). Salah satu produk pertanian yang menjadi kebutuhan pokok masyarakat Indonesia adalah terigu (Murtiningsih, 2011). Berbagai produk makanan seperti cake umumnya menggunakan terigu sebagai bahan baku.

$$
\text { Kebutuhan terigu Indonesia }
$$
terpenuhi dengan impor gandum karena Indonesia bukan negara penghasil gandum, hal ini berdampak pada meningkatnya impor terigu. Tahun 2015, impor terigu sudah mencapai 33.497 ton per tahun dan diperkirakan akan meningkat setiap tahunnya, sehingga perlu adanya upaya untuk mengurangi ketergantungan dalam impor terigu (Sarofa et al., 2014).

Terigu mengandung gluten yang membentuk tekstur pada cake, tetapi tidak 
semua orang dapat mengkonsumsi dan mencerna gluten dengan baik. Individu yang memiliki alergi terhadap gluten seperti penyandang intoleransi gluten dan autism spectrum disorder (ASD) harus menghindari gluten agar tidak timbul dampak buruk pada tubuh (Yustisia, 2013). Penyakit intoleransi gluten menyebabkan perubahan dalam usus halus sehingga terjadi gangguan penyerapan nutrisi yang masuk ke dalam tubuh, mengakibatkan timbulnya berbagai gangguan pada fungsi tubuh manusia.

Umbi-umbian merupakan salah satu bahan pangan lokal yang mudah didapatkan tanpa harus mengimport dari luar negeri. Umbi yang tinggi energi dan dapat digunakan sebagai alternatif bebas gluten salah satunya adalah singkong. Pengembangan singkong yang dimodifikasi dengan perlakuan fermentasi lalu diolah menjadi tepung, dikenal dengan nama mocaf (Salim, 2011).

Karakteristik mocaf mendukung untuk digunakan dalam pembuatan produk cake, karena memiliki pati yang lebih tinggi dari terigu, sehingga penambahan atau mengganti sebagian tepung dengan pati masih memungkinkan untuk dilakukan. Mocaf memiliki warna putih, tidak berbau singkong dan bisa diolah menjadi beragam makanan, contohnya cookies, cake, roti, dan mie. Keunggulan mocaf yaitu kandungan kalsium dan serat yang lebih tinggi dibandingkan dengan gandum serta tidak memiliki kandungan gluten, tetapi kandungan gizinya kurang lengkap sehingga perlu disubstitusi dengan labu kuning yang kaya akan $\beta$ karoten.Mengingat potensi labu kuning dan ketersediaannya yang melimpah di Indonesia dengan rerata produksi berkisar $20-21$ ton per hektar, sedangkan konsumsi labu kuning masih rendah yaitu sebesar kurang dari $5 \mathrm{~kg}$ perkapital per tahun (Widayati dan Damayanti, 2007). Pemanfaatan labu kuning dapat dijadikan tepung untuk menambah masa simpannya. Labu kuning memiliki kandungan zat gizi yang sangat banyak seperti mengandung $\beta$ karoten atau provitamin A, protein, karbohidrat, beberapa mineral seperti kalsium, fosfor, besi serta vitamin B dan C, dapat digunakan juga sebagai sumber antioksidan dan pewarna kuning alami serta mudah didapat (Rahmi et al., 2011).

Berdasarkan latar belakang tersebut, maka dilakukan penelitian untuk mengetahui pengaruh penambahan tepung labu kuning terhadap kerakteristik chiffon cake berbahan dasar mocaf untuk menambah variasi dalam pengolahan cake. Kandungan gizi dan sifat sensoris juga diharapkan meningkat sehingga dapat memanfaatkan bahan pangan lokal, serta mengurangi ketergantungan masyarakat pada terigu 


\section{BAHAN DAN METODE}

\section{Bahan dan Alat}

Bahan-bahan yang digunakan dalam melaksanakan penelitian ini terdiri dari bahan baku dan bahan kimia. Bahan baku yang digunakan dalam melaksanakan penelitian ini adalah labu kuning jenis bokor yang didapatkan dari Pasar Kreneng. Mocaf merk ladang lima, gula pasir lokal, susu bubuk merk dancow, garam, cream of tartar, minyak goreng merk bimoli dan baking powder didapatkan dari toko bahan kue UD. Fenny jalan Kartini No.83, Dauh Puri Kaja, Denpasar Utara, serta air yang digunakan adalah air mineral merk aqua yang diperoleh dari Pasar Kreneng. Bahan kimia yang digunakan dalam melakukan analisis kimia meliputi alkohol, aquades, $\beta$ karoten murni, kloroform, petroleum benzena, aseton dan $\mathrm{Na}_{2} \mathrm{SO}_{4}$

Alat yang digunakan untuk membuat chiffon cake adalah pisau, talenan, waskom, panci, kukusan, blender (Philips), mixer (Electrolux), timbangan digital (ACIS), gelas ukur (Pyrex), loyang, ayakan 80 mesh, sendok, spatula, oven, termometer, kompor gas (Rinnai) dan wajan. Alat yang digunakan untuk analisis sifat fisik dan kimia adalah lumpang, kertas saring, corong, eksikator, cawan porselin, botol timbang, oven (Memmert), timbangan analitik (Shimadzu), aluminium foil, pinset, muffle (Daihan), kompor listrik, pipet tetes, labu erlenmeyer (Pyrex), gelas beaker (Pyrex), gelas ukur (Pyrex), pipet volume
(Pyrex), pipet mikro (Socorex), pompa karet, labu takar (Pyrex), tabung reaksi (Pyrex), vortex (Maxi Mix II Type 367000), spektrofotometer (Thermo Scientific Genesis $10 S$ UV-Vis), lidi, penggaris, perangkat komputer dan lembar quisioner.

\section{Rancangan Percobaan}

Rancangan penelitian yang dipakai dalam penelitian ini adalah Rancangan Acak Kelompok (RAK) dengan perlakuan perbandingan tepung labu kuning dan mocaf terdiri dari 6 perlakuan yaitu: P1 (10\%: 90\%), P2 (20\%: 80\%), P3 (30\%: $70 \%)$, P4 (40\%: 60\%), P5 (50\% :50\%), P6 (60\% : 40\%). Diulang sebanyak 3 kali, sehingga didapat 18 unit percobaan. Data yang diperoleh dari hasil penelitian dianalisis dengan sidik ragam (ANOVA) melalui program SPSS 21 dan apabila perlakuan berpengaruh terhadap variabel maka dilanjutkan dengan uji Duncan's Multiple Range Test (DMRT) (Gomez dan Gomez, 1995). Perlakuan terbaik diperoleh dari uji objektif dan subjektif chiffon cake.

\section{Pelaksanaan Penelitian}

Proses Pembuatan Tepung Labu Kuning

Proses pembuatan chiffon cake meliputi beberapa tahapan, pertama dilakukan pembuatan tepung labu kuning dan dilanjutkan dengan pembuatan cake. Labu kuning dikupas, dibelah, dipisahkan dari kulitnya dan dibuang biji beserta serat bijinya sampai bersih serta dicuci dengan air mengalir. Diblansing dengan metode 
steam pada suhu $90^{\circ} \mathrm{C}$ selama 5 menit selanjutnya dipotong kecil- kecil dengan ketebalan $0,3 \mathrm{~cm}$ dan dikeringkan dalam oven pada suhu $60^{\circ} \mathrm{C}$ selama 12 jam. Dihancurkan dengan blender dan diayak menggunakan ayakan 80 mesh sehingga diperoleh tepung labu kuning.

\section{Proses Pembuatan Chiffon Cake}

Putih telur sebanyak $210 \%$ dikocok dengan mixer bersama cream of tartar sebanyak $1 \%$ dan gula pasir sebanyak $80 \%$ hingga kaku selama 5 menit, kemudian diwadah yang berbeda kuning telur sebanyak $80 \%$ dimixer selama 3 menit bersama minyak sebanyak $80 \%$, garam sebanyak $2 \%$, air sebanyak $70 \%$, susu bubuk sebanyak 30\%, dan gula pasir sebanyak 50\% hingga tercampur rata, tepung labu kuning $(10 \%, 20 \%, 30 \%, 40 \%$, $50 \%, 60 \%)$, mocaf $(90 \%, 80 \%, 70 \%, 60 \%$, $50 \%, 40 \%$ ) serta baking powder 2\% lalu dimasukkan dan dimixer hingga rata selama 2 menit. Adonan putih telur dimasukkan secara perlahan sambil diaduk menggunakan spatula ke dalam adonan kuning telur hingga rata. Adonan yang sudah tercampur dimasukkan ke dalam loyang dan dipanggang dalam oven pada suhu $180^{\circ} \mathrm{C}$ selama 30 menit. Chiffon cake yang sudah matang dikeluarkan dari loyang dan didinginkan.

\section{Variabel yang Diamati}

Variabel yang diamati dalam penelitian ini adalah kadar air dengan metode pengeringan (Sudarmadji et al., 1997), kadar abu dengan metode pengabuan (Sudarmadji et al., 1997), total karoten dengan metode spektrofotometri (Muchtadi, 1989), uji daya kembang (Haryadi, 1992) dan sifat sensoris menggunakan uji hedonik terhadap tekstur, aroma, rasa, warna, keseragaman pori dan penerimaan keseluruhan serta uji skoring terhadap tekstur, aroma, rasa, warna dan keseragaman pori (Soekarto, 1985).

\section{HASIL DAN PEMBAHASAN}

Hasil analisis kadar air, kadar abu, kadar protein, dan total karoten dari tepung labu kuning dan mocaf yang digunakan dapat dilihat pada Tabel 1 dan hasil analisis kadar air, kadar abu, total karoten dan daya kembang dari chiffon cake dapat dilihat pada Tabel 2.

Tabel 1. Nilai rata-rata hasil analisis kadar air, kadar abu dan total karoten dari tepung labu kuning dan mocaf.

\begin{tabular}{lcl}
\hline \multicolumn{1}{c}{ Komponen } & Tepung Labu Kuning & Mocaf \\
\hline Air $(\%)$ & 13,50 & 12,91 \\
Abu $(\%)$ & 5,62 & 0,38 \\
Total karoten $(\mu \mathrm{g} / \mathrm{g})$ & 204,29 & 0,00 \\
\hline
\end{tabular}


Tabel 2. Nilai rata-rata kadar air, kadar abu, total karoten dan daya kembang chiffon cake.

\begin{tabular}{lcccc}
\hline $\begin{array}{l}\text { Perbandingan } \\
\text { Tepung Labu Kuning } \\
\text { Dengan Mocaf }\end{array}$ & $\begin{array}{c}\text { Kadar } \\
\text { Air (\%) }\end{array}$ & $\begin{array}{c}\text { Kadar Abu } \\
(\%)\end{array}$ & $\begin{array}{c}\text { Total Karoten } \\
(\mu \mathrm{g} / \mathrm{g})\end{array}$ & $\begin{array}{c}\text { Daya } \\
\text { Kembang }(\%)\end{array}$ \\
\hline $10 \%: 90 \%(\mathrm{P} 1)$ & $34,06 \mathrm{e}$ & $0,99 \mathrm{c}$ & $5,81 \mathrm{f}$ & $582,48 \mathrm{f}$ \\
$20 \%: 80 \%(\mathrm{P} 2)$ & $35,16 \mathrm{~d}$ & $1,33 \mathrm{~b}$ & $11,66 \mathrm{e}$ & $564,99 \mathrm{e}$ \\
$30 \%: 70 \%$ (P3) & $36,65 \mathrm{c}$ & $1,38 \mathrm{~b}$ & $27,39 \mathrm{~d}$ & $511,65 \mathrm{~d}$ \\
$40 \%: 60 \%$ (P4) & $36,89 \mathrm{c}$ & $1,45 \mathrm{ab}$ & $31,83 \mathrm{c}$ & $478,31 \mathrm{c}$ \\
$50 \%: 50 \%$ (P5) & $38,08 \mathrm{~b}$ & $1,56 \mathrm{ab}$ & $40,77 \mathrm{~b}$ & $449,98 \mathrm{~b}$ \\
$60 \%: 40 \%(\mathrm{P} 6)$ & $40,30 \mathrm{a}$ & $1,74 \mathrm{a}$ & $50,62 \mathrm{a}$ & $409,98 \mathrm{a}$ \\
\hline
\end{tabular}

Keterangan : Nilai rata - rata yang diikuti oleh huruf yang berbeda pada kolom yang sama menunjukkan berbeda nyata pada Uji Duncan 0,05 .

\section{Kadar Air}

Hasil sidik ragam menunjukkan bahwa perbandingan tepung labu kuning dengan mocaf berpengaruh sangat nyata $(\mathrm{P}<0,01)$ terhadap kadar air chiffon cake. Tabel 2 menunjukkan kadar air terendah chiffon cake diperoleh pada perlakuan P1 yaitu $34,06 \%$ sedangkan kadar air tertinggi chiffon cake diperoleh pada perlakuan P6 yaitu $40,30 \%$.

Peningkatan kadar air chiffon cake disebabkan oleh bertambahnya konsentrasi tepung labu kuning, semakin banyak penambahan tepung labu kuning semakin tinggi kadar air chiffon cake. Hal ini disebabkan oleh tepung labu kuning memiliki kadar air yang lebih besar dibandingkan mocaf. Berdasarkan hasil analisis bahan baku, kandungan kadar air tepung labu kuning lebih tinggi yaitu sebesar 13,50\% dibandingkan dengan mocaf yaitu sebesar 12,91\% (Tabel 1).

\section{Kadar Abu}

Hasil sidik ragam menunjukkan bahwa perbandingan tepung labu kuning dengan mocaf berpengaruh sangat nyata
$(\mathrm{P}<0,01)$ terhadap kadar abu chiffon cake. Tabel 2 menunjukkan kadar abu chiffon cake terendah diperoleh pada perlakuan P1 yaitu $0,99 \%$, sedangkan kadar abu tertinggi chiffon cake diperoleh pada perlakuan P6 yaitu $1,74 \%$. Penentuan kadar abu bertujuan untuk mengetahui banyaknya kandungan mineral yang terdapat dalam chiffon cake. Kadar abu chiffon cake tinggi pada perlakuan P6 seiring dengan tingginya penambahan tepung labu kuning.

Hal ini dikarenakan tepung labu kuning mengandung mineral lebih tinggi dibandingkan dengan mocaf sehingga jumlahnya semakin besar seiring dengan penambahan tepung labu kuning. Menurut Astawan (2008), kadar abu tepung labu kuning sebesar 5,45\% lebih besar dibanding kadar abu mocaf yaitu sebesar 0,4\% (Salim, 2011). Berdasarkan hasil analisis bahan baku kadar abu tepung labu kuning yaitu 5,62\% lebih besar dari kadar abu mocaf yaitu $0,38 \%$ (Tabel 1). Kandungan mineral dalam labu kuning adalah kalsium $(45,00 \mathrm{mg} / 100 \mathrm{~g})$, fosfor $(64,00 \mathrm{mg} / 100 \mathrm{~g})$ dan besi $(1,40 \mathrm{mg} / 100 \mathrm{~g})$ 
(Hendrasty, 2003). Mineral berfungsi sebagai zat pembangun dan pengatur di dalam tubuh. Beberapa fungsi mineral dalam tubuh diantaranya kalsium berperan dalam membentuk tulang dan gigi serta mengatur proses biologis, fosfor berperan dalam penyimpanan dan pengeluaran energi (Winarno, 2004).

\section{Total Karoten}

Hasil sidik ragam menunjukkan bahwa perbandingan tepung labu kuning dengan mocaf berpengaruh sangat nyata $(\mathrm{P}<0,01)$ terhadap total karoten chiffon cake. Tabel 2 menunjukkan total karoten terendah chiffon cake diperoleh pada perlakuan P1 yaitu 5,81 $\mu \mathrm{g} / \mathrm{g}$ sedangkan total karoten tertinggi chiffon cake diperoleh pada perlakuan P6 yaitu 50,62 $\mu \mathrm{g} / \mathrm{g}$. Total karoten chiffon cake bertambah seiring dengan tingginya konsentrasi penambahan tepung labu kuning. Berdasarkan hasil analisis bahan baku total karoten tepung labu kuning yaitu 204,29 $\mu \mathrm{g} / \mathrm{g}$ lebih besar dari pada total karoten mocaf yaitu $0,00 \mu \mathrm{g} / \mathrm{g}$ (Tabel 1). $\beta$-karoten merupakan sumber terbaik dari salah satu vitamin penting yakni vitamin A yang diperlukan untuk meningkatkan kesehatan mata dan kulit.

\section{Daya Kembang}

Hasil sidik ragam menunjukkan bahwa perbandingan tepung labu kuning dengan mocaf berpengaruh sangat nyata $(\mathrm{P}<0,01)$ terhadap daya kembang chiffon cake. Tabel 2 menunjukkan daya kembang terendah chiffon cake diperoleh pada perlakuan P6 yaitu 409,98\% sedangkan daya kembang tertinggi chiffon cake diperoleh pada perlakuan P1 yaitu $582,48 \%$.

Daya kembang chiffon cake semakin berkurang seiring dengan bertambahnya konsentrasi penambahan tepung labu kuning. Hal ini disebabkan karena kandungan pati pada tepung labu kuning lebih kecil dari pati pada mocaf yang menyebabkan daya kembangnya menurun seiring dengan penambahan tepung labu kuning. Pati akan menyerap air dan terjadi reaksi gelatinisasi lalu $\mathrm{CO}_{2}$ akan terperangkap dalam butiran pati sehingga adonan akan mengembang. Pengembangan terjadi pada saat adonan memasuki oven yang panas, adonan bertemu dengan udara panas pada ruang pemanggang dan lapisan luar cake tampak terbentuk pada permukaan adonan serta terjadi pengembangan cake, selama itu terjadi pengembangan volume adonan (Desrosier, 2008)

\section{Evaluasi Sifat Sensoris}

Nilai rata-rata uji hedonik terhadap keseragaman pori, warna, aroma, tekstur, rasa dan penerimaan keseluruhan chiffon cake dapat dilihat pada Tabel 3. Nilai ratarata uji skoring terhadap keseragaman pori, warna, aroma, tekstur dan rasa dapat dilihat pada pada Tabel 4 . 
Tabel 3. Nilai rata - rata uji hedonik keseragaman pori, warna, aroma, tekstur, rasa dan penerimaan keseluruhan chiffon cake

\begin{tabular}{ccccccc}
\hline Perbandingan & \multicolumn{5}{c}{ Nilai rata - rata uji hedonik } \\
$\begin{array}{c}\text { Tepung Labu } \\
\text { Kuning dengan } \\
\text { Mocaf }\end{array}$ & $\begin{array}{c}\text { Keseragaman } \\
\text { Pori }\end{array}$ & Warna & Aroma & Tekstur & Rasa & $\begin{array}{c}\text { Penerimaan } \\
\text { Keseluruhan }\end{array}$ \\
\hline $10 \%: 90 \%(\mathrm{P} 1)$ & $5.65 \mathrm{ab}$ & $5.25 \mathrm{~b}$ & $4.95 \mathrm{ab}$ & $5.95 \mathrm{ab}$ & $5.80 \mathrm{~b}$ & $5.85 \mathrm{~b}$ \\
$20 \%: 80 \%(\mathrm{P} 2)$ & $5.70 \mathrm{a}$ & $5.75 \mathrm{a}$ & $5.05 \mathrm{a}$ & $6.10 \mathrm{a}$ & $6.25 \mathrm{a}$ & $6.00 \mathrm{a}$ \\
$30 \%: 70 \%(\mathrm{P} 3)$ & $5.60 \mathrm{abc}$ & $6.05 \mathrm{a}$ & $5.25 \mathrm{a}$ & $6.05 \mathrm{a}$ & $6.20 \mathrm{a}$ & $6.25 \mathrm{a}$ \\
$40 \%: 60 \%(\mathrm{P} 4)$ & $5.40 \mathrm{bcd}$ & $5.85 \mathrm{a}$ & $5.20 \mathrm{a}$ & $5.70 \mathrm{ab}$ & $5.25 \mathrm{c}$ & $5.75 \mathrm{~b}$ \\
$50 \%: 50 \%(\mathrm{P} 5)$ & $5.30 \mathrm{~d}$ & $4.20 \mathrm{c}$ & $4.60 \mathrm{~b}$ & $5.80 \mathrm{abc}$ & $4.45 \mathrm{~d}$ & $5.75 \mathrm{~b}$ \\
$60 \%: 40 \%(\mathrm{P} 6)$ & $5.35 \mathrm{~cd}$ & $4.05 \mathrm{c}$ & $4.55 \mathrm{~b}$ & $5.60 \mathrm{c}$ & $4.05 \mathrm{e}$ & $5.70 \mathrm{~b}$ \\
\hline
\end{tabular}

Keterangan : Nilai rata - rata yang diikuti oleh huruf yang berbeda pada kolom yang sama menunjukkan berbeda nyata pada Uji Duncan 0,05 .

Kriteria hedonik : 1 (sangat tidak suka), 2 (tidak suka), 3 (agak tidak suka), 4 (biasa), 5 (agak suka), 6 (suka), 7 (sangat suka).

\section{Keseragaman Pori}

Hasil sidik ragam menunjukkan bahwa perbandingan tepung labu kuning dengan mocaf berpengaruh nyata $(\mathrm{P}<0,05)$ terhadap keseragaman pori (uji hedonik) chiffon cake. Tabel 4 menunjukkan nilai tertinggi kesukaan panelis terhadap keseragaman pori chiffon cake diperoleh pada perlakuan P2 yaitu 5,70 (suka)

serta tidak berbeda dengan perlakuan P1 dan P3 sedangkan nilai kesukaan terendah diperoleh pada perlakuan P5 yaitu 5,30 (agak suka) serta tidak berbeda dengan perlakuan P4 dan P6. Perbandingan tepung labu kuning dengan mocaf berpengaruh sangat nyata $(\mathrm{P}<0,01) \quad$ terhadap keseragaman pori (uji skoring) chiffon cake.
Tabel 5 menunjukkan bahwa nilai penerimaan terhadap keseragaman pori uji skoring chiffon cake tertinggi diperoleh pada perlakuan P1 yaitu 4,20 (seragam) dan terendah diperoleh pada perlakuan P6 yaitu 3.05 (agak seragam).

Panelis lebih menyukai chiffon cake dengan perlakuan P2 yang keseragaman porinya seragam, hal ini disebabkan karena chiffon cake dengan penambahan tepung labu kuning yang semakin banyak membuat ukurannya semakin tidak seragam dikarenakan tepung labu kuning memiliki kadar air yang lebih tinggi dibandingkan mocaf selain itu tepung labu kuning tidak mengandung gluten yang mempunyai sifat menahan gas $\mathrm{CO} 2$ sehingga akan membentuk pori yang sedikit dan tidak seragam. 
Tabel 4. Nilai rata-rata uji skoring keseragaman pori, warna, aroma, tekstur dan rasa chiffon cake

\begin{tabular}{lccccc}
\hline \multirow{2}{*}{$\begin{array}{c}\text { Perbandingan } \\
\text { Tepung Labu Kuning } \\
\text { dengan Mocaf }\end{array}$} & \multicolumn{5}{c}{ Nilai rata - rata uji skoring } \\
\cline { 2 - 6 } & $\begin{array}{c}\text { Keseragaman } \\
\text { Pori }\end{array}$ & Warna & Aroma & Tekstur & Rasa \\
\hline $10 \%: 90 \%(\mathrm{P} 1)$ & $4.20 \mathrm{a}$ & $2.15 \mathrm{~d}$ & $1.50 \mathrm{e}$ & $4.14 \mathrm{a}$ & $1.50 \mathrm{e}$ \\
$20 \%: 80 \%(\mathrm{P} 2)$ & $3.95 \mathrm{a}$ & $2.30 \mathrm{~d}$ & $1.85 \mathrm{~d}$ & $4.20 \mathrm{a}$ & $2.10 \mathrm{~d}$ \\
$30 \%: 70 \%(\mathrm{P} 3)$ & $3.90 \mathrm{a}$ & $3.05 \mathrm{c}$ & $2.65 \mathrm{c}$ & $4.05 \mathrm{a}$ & $2.65 \mathrm{c}$ \\
$40 \%: 60 \%(\mathrm{P} 4)$ & $3.60 \mathrm{~b}$ & $3.70 \mathrm{~b}$ & $3.30 \mathrm{~b}$ & $3.35 \mathrm{~b}$ & $3.50 \mathrm{~b}$ \\
$50 \%: 50 \%(\mathrm{P} 5)$ & $3.25 \mathrm{c}$ & $4.30 \mathrm{a}$ & $4.00 \mathrm{a}$ & $3.30 \mathrm{~b}$ & $4.15 \mathrm{a}$ \\
$60 \%: 40 \%(\mathrm{P} 6)$ & $3.05 \mathrm{c}$ & $4.65 \mathrm{a}$ & $4.45 \mathrm{a}$ & $3.10 \mathrm{~b}$ & $4.45 \mathrm{a}$ \\
\hline
\end{tabular}

Keterangan: Nilai rata - rata yang diikuti oleh huruf yang berbeda pada kolom yang sama menunjukkan berbeda nyata pada Uji Duncan 0,05 .

Kriteria keseragaman pori : 1 (sangat tidak seragam), 2 (tidak seragam), 3 (agak seragam), 4 (seragam), 5 (sangat seragam).

Kriteria warna :1 (putih kekuningan), 2 (kuning muda), 3 (kuning), 4 (kuning tua), 5 (kuning kecoklatan).

Kriteria aroma :1 (tidak beraroma labu kuning), 2 (aroma labu kuning lemah), 3 (aroma labu kuning sedang), 4 (aroma labu kuning kuat), 5 (aroma labu kuning sangat kuat).

Kriteria tekstur :1(tidak lembut), 2 (agak tidak lembut), 3 (agak lembut), 4 (lembut), 5 (sangat lembut).

Kriteria rasa $\quad: 1$ (tidak khas labu kuning), 2 (kurang khas labu kuning), 3 (agak khas labu kuning), 4 (khas labu kuning), 5 (sangat khas labu kuning).

\section{Warna}

Hasil sidik ragam menunjukkan bahwa perbandingan tepung labu kuning dengan mocaf berpengaruh sangat nyata $(\mathrm{P}<0,01)$ terhadap warna chiffon cake (uji hedonik). Tabel 3 menunjukkan bahwa nilai tertinggi tingkat kesukaan panelis terhadap warna chiffon cake diperoleh pada perlakuan P3 yaitu 6,05 (suka) serta tidak berbeda dengan perlakuan P2 dan P4 sedangkan nilai kesukaaan terendah diperoleh pada perlakuan P6 yaitu 4,05 (biasa). Perbandingan tepung labu kuning dengan mocaf berpengaruh sangat nyata $(\mathrm{P}<0,01)$ terhadap warna (uji skoring) chiffon cake. Tabel 4 menunjukkan bahwa nilai penerimaan terhadap warna uji skoring chiffon cake tertinggi diperoleh pada perlakuan P6 yaitu 4,65 (kuning kecoklatan) dan terendah diperoleh pada perlakuan P1 yaitu 2,15 (kuning muda).

Panelis lebih menyukai chiffon cake dengan perlakuan P3 yang berwarna kuning dibandingkan yang berwarna kuning muda atau kuning tua, hal ini disebabkan karena penambahan tepung labu kuning lebih menarik minat panelis, tetapi semakin tinggi penambahan tepung labu kuning kesukaan panelis menurun karena warna kuning yang dihasilkan kecoklatan dan lebih pekat. Hal ini disebabkan warna pada tepung labu kuning yang dominan berwarna kuning-jingga sehingga mempengaruhi 
warna produk akhir makanan (See et al., 2007).

\section{Aroma}

Hasil sidik ragam menunjukkan bahwa perbandingan tepung labu kuning dengan mocaf berpengaruh nyata $(\mathrm{P}<0,05)$ terhadap aroma chiffon cake. Tabel 4 menunjukkan bahwa nilai tertinggi tingkat kesukaan panelis terhadap aroma chiffon cake diperoleh pada perlakuan P3 yaitu 5,25 (agak suka) serta tidak berbeda dengan perlakuan P1, P2 dan P4 sedangkan nilai kesukaaan terendah diperoleh pada perlakuan P6 yaitu 4,55 (agak suka) serta tidak berbeda dengan P5 dan P1. Perbandingan tepung labu kuning dengan mocaf berpengaruh sangat nyata $(\mathrm{P}<0,01)$ terhadap aroma (uji skoring) chiffon cake. Tabel 5 menunjukkan bahwa nilai penerimaan terhadap aroma uji skoring chiffon cake tertinggi diperoleh pada perlakuan P6 yaitu 4,45 (aroma labu kuning kuat) serta tidak berbeda dengan perlakuan P5, dan terendah diperoleh pada perlakuan P1 yaitu 1,50 (aroma labu kuning lemah).

Panelis lebih menyukai chiffon cake dengan perlakuan P3 yang beraroma labu kuning sedang. Hal ini disebabkan karena semakin tinggi konsentrasi tepung labu kuning sehingga aroma labu kuning pada chiffon cake semakin kuat. Menurut Meilgaard, et al. (2000) menyatakan bahwa aroma makanan timbul disebabkan oleh terbentuknya senyawa volatil yang mudah menguap, selain itu proses pemasakan yang berbeda akan menimbulkan aroma yang berbeda.

\section{Tekstur}

Hasil sidik ragam menunjukkan bahwa perbandingan tepung labu kuning dengan mocaf berpengaruh nyata $(\mathrm{P}<0,05)$ terhadap tekstur chiffon cake (uji hedonik). Tabel 4 menunjukkan bahwa nilai tertinggi tingkat kesukaan panelis terhadap tekstur chiffon cake diperoleh pada perlakuan P2 yaitu 6,10 (suka) serta tidak berbeda dengan perlakuan P1, P3, P4 dan P5 sedangkan nilai kesukaaan terendah diperoleh pada perlakuan P6 yaitu 5,60 (suka). Perbandingan tepung labu kuning dengan mocaf berpengaruh sangat nyata $(\mathrm{P}<0,01)$ terhadap tekstur (uji skoring) chiffon cake. Tabel 5 menunjukkan bahwa nilai penerimaan terhadap tekstur uji skoring chiffon cake tertinggi diperoleh pada perlakuan P2 yaitu 4,20 (lembut) serta tidak berbeda dengan P1 dan P3, sedangkan nilai terendah diperoleh pada perlakuan P6 yaitu 3,10 (agak lembut) serta tidak berbeda dengan perlakuan P4 dan P5.

Panelis lebih menyukai chiffon cake dengan perlakuan P2 yang bertekstur lembut. Hal ini disebabkan karena semakin tinggi konsentrasi penambahan tepung labu kuning menyebabkan kekerasan meningkat sebagai akibat pengembangan yang kurang baik atau menurunkan volume chiffon cake sehingga menjadi lebih padat dan terasa lebih keras, serta lebih sedikit pori pada produk yang dihasilkan. Semakin sedikit 
jumlah pori yang dihasilkan maka semakin tidak seragam penampakannya sehingga tekstur chiffon cake yang dihasilkan semakin tidak lembut (Desrosier, 2008).

\section{Rasa}

Hasil sidik ragam menunjukkan bahwa perbandingan tepung labu kuning dengan mocaf berpengaruh sangat nyata $(\mathrm{P}<0,01)$ terhadap rasa chiffon cake. Tabel 4 menunjukkan bahwa nilai tertinggi tingkat kesukaan panelis terhadap rasa chiffon cake diperoleh pada perlakuan P2 yaitu 6,25 (suka) serta tidak berbeda dengan perlakuan P2 sedangkan nilai kesukaaan terendah diperoleh pada perlakuan P6 yaitu 4,05 (suka). Perbandingan tepung labu kuning dengan mocaf berpengaruh sangat nyata $(\mathrm{P}<0,01)$ terhadap rasa (uji skoring) chiffon cake. Tabel 5 menunjukkan bahwa nilai rata-rata penerimaan terhadap rasa uji skoring chiffon cake tertinggi diperoleh pada perlakuan P6 yaitu 4,45 (sangat khas labu kuning) serta tidak berbeda dengan P5 dan terendah diperoleh pada perlakuan P1 yaitu 1,50 (kurang khas labu kuning).

Panelis lebih menyukai chiffon cake dengan perlakuan P2 dengan rasa kurang khas labu kuning. Menurut Khasanah (2003), menyatakan bahwa rasa adalah faktor yang dinilai panelis setelah tekstur, warna dan aroma yang dapat yang mempengaruhi penerimaan produk pangan. Rasa yang enak dapat menarik perhatian sehingga konsumen lebih cenderung menyukai makanan dibandingkan rasanya.
Jika komponen aroma, warna dan tekstur baik tetapi konsumen tidak menyukai rasanya maka konsumen tidak akan menerima produk pangan tersebut.

\section{Penerimaan Keseluruhan}

Hasil sidik ragam menunjukkan bahwa perbandingan tepung labu kuning dengan mocaf berpengaruh nyata $(\mathrm{P}<0,05)$ terhadap penerimaan keseluruhan chiffon cake. Tabel 4 menunjukkan bahwa nilai tertinggi tingkat kesukaan panelis terhadap penerimaan keseluruhan chiffon cake diperoleh pada perlakuan P3 yaitu 6,25 (suka) serta tidak berbeda dengan perlakuan P2 sedangkan nilai kesukaaan terendah diperoleh pada perlakuan P6 yaitu 5,70 (agak suka). Penerimaan keseluruhan chiffon cake dipengaruhi oleh beberapa faktor seperti keseragaman pori, warna, aroma, tekstur dan rasa.

\section{KESIMPULAN DAN SARAN}

\section{Kesimpulan}

1. Perbandingan tepung labu kuning dengan mocaf berpengaruh terhadap kadar air, kadar abu, daya kembang, total karoten, uji hedonik (keseragaman pori, warna, aroma, tekstur, rasa dan penerimaan keseluruhan) dan uji skoring (keseragaman pori, warna, aroma, tekstur, rasa) chiffon cake.

2. Perbandingan $30 \%$ labu kuning : $70 \%$ mocaf merupakan karakteristik terbaik chiffon cake dengan kriteria kadar air 
$36,65 \%$, kadar abu 1,38\%, daya kembang 511,65\%, total karoten 27,39 $\mu \mathrm{g} / \mathrm{g}$, keseragaman pori seragam dan suka, warna kuning dan suka, aroma labu kuning sedang dan agak suka, tekstur lembut dan suka, rasa agak khas labu kuning dan suka serta penerimaan keseluruhan suka.

\section{Saran}

Berdasarkan hasil penelitian ini disarankan untuk menggunakan perbandingan 30\% tepung labu kuning: $70 \%$ mocaf dalam proses pembuatan chiffon cake.

\section{DAFTAR PUSTAKA}

Astawan, M. 2008. Teknologi Pengolahan Pangan Nabati Tepat Guna. Akademi Pressido, Jakarta

Desrosier, N.W. 2008. Teknologi Pengawetan Pangan. Edisi ketiga. Penerjemah M. Miljohardjo. UIPress, Jakarta.

Haryadi, J. 1992. Fisiko Kimiawi dan Teknologi Bahan Berpati. PAU Pangan dan Gizi UGM, Yogyakarta.

Hendrasty, H. K. 2003. Tepung Labu Kuning Pembuatan dan Pemanfaatannya. Karnisius, Yogyakarta.

Khasanah, U. 2003. Formulasi Karakterisasi Fisiko-Kimia dan Organoleptik Produk Makanan Sarapan Ubi Jalar (Sweet Potato Flakes). Skripsi. Fakultas Teknologi Pertanian. Institut Pertanian Bogor. Bogor.

McWilliams, M. 1997. Foods Experimental Perspectives 3rd Edition.cPrenticeHal Inc, New Jersey.

Muchtadi, T. 1989. Teknologi Proses Pengolahan Pangan. Direktorat
Jenderal Pendidikan Tinggi. Pusat Antar Universitas Pangan dan Gizi Institut Pertanian Bogor, Bogor.

Murtiningsih, S. 2011. Membuat Tepung Umbi dan Variasi Olahannya. Agromedia Pustaka, Jakarta.

Meilgaard, M., G. V. Civille dan B. T. Carr. 2000. Sensory Evaluation Techniques. Boca Raton, Florida : CRC Press.

Rahmi, S.L., A. Indriyani., dan L. Surhaini. 2011. Penggunaan Buah Labu Kuning sebagai Sumber Antioksidan dan Pewarna Alami pada Produk Mie Basah. Fakultas Pertanian, Universitas Jambi. Vol. 13. (2) : 2936.

Salim, E. 2011. Mengolah Singkong Menjadi tepung Mocaf Bisnis Produk Alternatif Pengganti Terigu, Yogyakarta.

Sarofa, U., S.Djajati., dan S.N. Cholifah. 2014. Pembuatan Roti Manis (Kajian Substitusi Tepung Terigu Dan Kulit Manggis Dengan Penambahan Gluten). Jurnal Rekapangan Vol. 8 No.2. Hal. 171178.

See, E. F., W. Nadiah., dan A. Noor. 2007. Physico-Chemical and Organoleptic Evaluations of Wheat Bread Substituted with Different Percentage of Pumpkin Flour (Cucurbita moschata). ASEAN Food Journal, Vol. 14 ( 2) : 123130.

Soekarto, S.T. 1985. Penilaian Organoleptik untuk Industri Pangan dan Hasil Pertanian. Bhratara Karya Aksara, Jakarta.

Sudarmadji, S., B. Haryono., dan Suhardi. 1997. Prosedur Analisa untuk Bahan Makanan dan Pertanian. Liberty, Yogyakarta.

Widayati, E dan Damayanti, W. 2007. Aneka Pengolahan dari Labu kuning. Trubus Agrisarana. Jakarta. 
Winarno, F. G. 2004. Kimia Pangan dan Gizi. PT. Gramedia, Jakarta.

Yustisia, R. 2013. Pengaruh Penambahan Telur Terhadap Kadar Protein, Serat, Tingkat Kekenyalan dan Penerimaan Mie Basah Bebas Gluten Berbahan Baku Tepung Komposit. Journal of Nutrition College, 2 (4): 697-703. 